\title{
Correction to: Objective and Subjective Effects of a Prototype Nasal Dilator Strip on Sleep in Subjects with Chronic Nocturnal Nasal Congestion
}

\author{
John R. Wheatley $\cdot$ Terence C. Amis $\cdot$ Sharon A. Lee $\cdot$ Renee Ciesla \\ Gilbert Shanga
}

Published online: September 4, 2019

(C) The Author(s) 2019

Correction to: Adv Ther (2019) 36:1657-1671

https://doi.org/10.1007/s12325-019-00980-z

The article "Objective and Subjective Effects of a Prototype Nasal Dilator Strip on Sleep in Subjects with Chronic Nocturnal Nasal Congestion", written by John R. Wheatley, Terence C. Amis, Sharon A. Lee, Renee Ciesla, and Gilbert Shanga, was originally published electronically on the publisher's internet portal (currently SpringerLink) on May 22, 2019 without Open Access. The article has now been made Open Access.

The original article can be found online at https://doi. org/10.1007/s12325-019-00980-z.

J. R. Wheatley $(\bowtie) \cdot$ T. C. Amis · S. A. Lee

University of Sydney at Westmead Hospital,

Westmead, NSW, Australia

e-mail: john.wheatley@sydney.edu.au

J. R. Wheatley · T. C. Amis . S. A. Lee

Ludwig Engel Centre for Respiratory Research,

Westmead Institute for Medical Research,

Westmead, NSW, Australia

R. Ciesla · G. Shanga

GlaxoSmithKline Consumer Healthcare, Warren,

NJ, USA

The copyright of the article has been changed to The Author(s) 2019 and the article is forthwith distributed under the terms of the Creative Commons Attribution-NonCommercial 4.0 International License (http://creative commons.org/licenses/by-nc/4.0/), which permits any non-commercial use, distribution, and reproduction in any medium, provided you give appropriate credit to the original author(s) and the source, provide a link to the Creative Commons license, and indicate if changes were made.

The original article has been updated.

Open Access. This article is distributed under the terms of the Creative Commons Attribution-NonCommercial 4.0 International License (http://creativecommons.org/licenses/ by-nc/4.0/), which permits any noncommercial use, distribution, and reproduction in any medium, provided you give appropriate credit to the original author(s) and the source, provide a link to the Creative Commons license, and indicate if changes were made. 